\title{
Seed Quality of Stored Soybean (Glycine max L.) as Influenced by Storage Containers and Storage Periods
}

\author{
N. Akter ${ }^{1}$, M. M. Haque ${ }^{1}$, M. R. Islam ${ }^{1}$ and K. M. Alam ${ }^{2}$ \\ ${ }^{1}$ Dept. of Agronomy, Bangabandhu Sheikh Mujibur Rahman Agricultural University, Gazipur- \\ 1706, Bangladesh; ${ }^{2}$ Bangladesh Agricultural Research Institute (BARI), Gazipur-1701 \\ *Corresponding author and Email: lata.agr@gmail.com
}

Received: 12 February $2014 \quad$ Accepted: 14 June 2014

\begin{abstract}
An experiment was conducted at Bangabandhu Sheikh Mujibur Rahman Agricultural University, Gazipur during April 2013 to June 2013 to study the effect of three storage containers (tin container, polythene bag and cloth bag); and five storage periods $(0,15,30,45$, and 60 days) on the seed quality of soybean. The experiment was laid out in Completely Randomized Design (CRD) with four replications. The soybean seeds stored in tin container showed maximum germination capacity with high germination index, highest seedling growth, seedling dry weight per plant and vigour index. The seeds stored in cloth bag had the lowest seed quality during the testing period. The highest 1000 -seed weight, moisture content, electrical conductivity, abnormal seedlings and number of dead seeds were recorded in cloth bag; where the equivalent lowest values were recorded in tin container. The moisture content, 1000-seed weight, electrical conductivity, number of abnormal seedlings and dead seeds were increased with the longer period of storage. In addition, germination index, seedling growth, dry weight per plant of soybean seedling, and vigor index decreased with the increase in storage period. Among the three containers, tin container was the best and the cloth bag was the worst storage container for soybean seed storage for long period.
\end{abstract}

Keywords: Soybean, seed quality, storage container, storage period

\section{Introduction}

Soybean (Glycine max L.) is a very important protein rich oilseed crop extensively grown in the tropical, sub-tropical as well as the temperate region. Soybean oil is the largest component of the world's edible oils. The world production of edible oils consists of $30 \%$ soybean (Assefa, 2008). Soybean seed contains about $40-45 \%$ protein and $20-22 \%$ oil, $20-26 \%$ carbohydrate and a high amount of $\mathrm{Ca}, \mathrm{P}$ and vitamins (Rahman et al., 2011). In Bangladesh, in terms of area and production, soybean is a negligible crop concentrated in a very few locations.
During the period 2009-10 in Bangladesh, cultivation of soybean covered about 55,000 hectares of land and produced about 90,000 metric tones of seeds (Anonymous, 2011). The country's total demand for edible oil is around 1.3 million metric tons per year. Of the amount, 0.15 to 0.2 million metric tons come from mustard oil while the rest is met with imported soybean, rapeseed and palm oil (Rahman and Chowdhury, 2010).

Regardless of the high yield potential and other advantages, the average yield of soybean in Bangladesh is very low $\left(1500-2000 \mathrm{~kg} \mathrm{ha}^{-1}\right)$ 
(BBS, 2009). However, Soybean cultivation is hindered due to lack of good quality seed (Rahman et al., 2013; Amin et al., 2009). Quality seed can increase the yield upto $30 \%$ keeping the other production factors the same (BARI, 1993). Quality seed that provides adequate plant stand is the basis for profitable production and expansion of soybean crop. In order to increase the production of soybean, a source of high quality, disease free seed must be established and maintained.

Storage condition is the key part of the maintenance of seed quality during storage. Generally, the quality of seed of soybean deteriorates during the storage period. In Bangladesh, seed quality deteriorates at the time of storage due to the prevailing bad weather which favours insect, and disease attack. Poor storage conditions greatly affect seed vigour (Heydecker, 1979); reduce respiration and seedling size. Exposure of seeds to moisture, temperature, relative humidity and activity of pests are related to the retention of seed viability in storage. Types of container also regulate temperature, relative humidity, and seed moisture content. Therefore, it is necessary to store seeds in suitable containers. Indeed, types of container that can provide suitable condition to maintain seed quality for longer period is very essential for seed preservation.

However, very little work has been carried out in Bangladesh in this regard. Keeping this in view, the present study was undertaken to determine the effect of different storage containers and storage periods on the seed quality of stored soybean.

\section{Materials and Methods}

\subsection{Experimental site and design}

The experiment was conducted at the Bangabandhu Sheikh Mujibur Rahman Agricultural University (BSMRAU), Gazipur during April 2013 to June 2013. BARI Soybean5 was used in the experiment. The experiment was laid out in the Completely Randomized
Design (CRD) with four replications. Three storage containers: 1) tin container, 2) polythene bag and 3) cloth bag); and five storage periods $(0,15,30,45$, and 60 days) were used in this experiment. Seeds were stored at room temperature $\left(24\right.$ to $30^{\circ} \mathrm{C}$ ) and relative humidity (70 to $82 \%$ ) up to 60 days. Seed samples were taken randomly from each storage container and were tested at the end of each storage period as described above. Quality of soybean seeds was assessed by moisture content, viability, vigour index, electrical conductivity and observation of biotic factors as per the following procedures.

\subsection{Data Collection and Statistical Analysis}

\subsubsection{Moisture content test}

Moisture content was determined at every 15 days during experimental period by using low constant temperature oven method $\left(103^{\circ} \mathrm{C}, 18 \mathrm{hr}\right)$ following International Rules for Seed Testing (ISTA, 1999) in the seed Technology Laboratory of BSMRAU. The moisture content of seed (wet basis) was determined following the formula (Anonymous, 1999):

$$
\begin{aligned}
& \text { MC }(\%)=\frac{M_{2}-M_{3}}{M_{2}-M_{1}} \times 100 \\
& \text { Where, } \\
& M_{1}=\text { wt. of container }+ \text { cover } \\
& M_{2}=\begin{array}{l}
\text { wt. of container }+ \text { cover }+ \text { soybean seed } \\
\text { before drying }
\end{array} \\
& M_{3}=\begin{array}{l}
\text { wt. of container }+ \text { cover }+ \text { soybean seed } \\
\text { after drying }
\end{array}
\end{aligned}
$$

\subsubsection{Viability test}

Viability test was done through germination test. Four hundred seeds were tested for germination from each container for every storage period in the pots as per the rules of ISTA, 1999. In pot, germination test was conducted using sand as substratum. The plastic pots were placed in room temperature $\left(24\right.$ to $\left.30^{\circ} \mathrm{C}\right)$ for germination. Seedlings were counted every day up to the completion of germination at the fifteenth day. Data on abnormal seedlings, dead seeds, and shoot and root lengths were recorded from the experiment. Abnormality of the seedlings was 
determined according to the prescribed rules given by ISTA (1999). Germination percentage was calculated following Krishnasamy and Seshu (1990) as:

$$
\begin{aligned}
& \text { Germination }(\%)= \\
& \frac{\text { Number of seeds germinated }}{\text { Number of seeds tested }} \times 100
\end{aligned}
$$

\subsubsection{Germination index (GI)}

The germination index (GI) was calculated as described in the Association of Official Seed Analysts (AOSA, 1983).

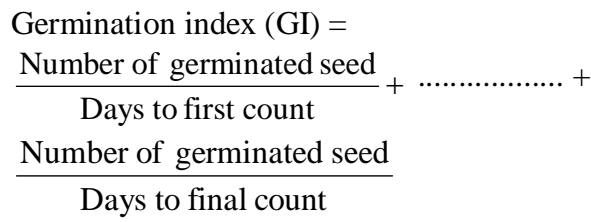

\subsubsection{Seed vigour index}

This was calculated by determining the germination percentage and seedling length of the same seed lot. For seed vigour index data were recorded on germination up to 15 days of sowing. Then root length and shoot length were measured from seedlings of pots for calculating seed vigour index. Seed vigour index was calculated using the following formula (Baki and Anderson, 1970):

Seed vigour index $=$ Germination $(\%) \mathrm{X}$ (Mean shoot length + Mean root length)

\subsubsection{Seedling vigour index}

Ten plant samples from each pot were harvested on the day 15 of the germination test and dried at $70^{\circ} \mathrm{C}$ for 72 hours for dry matter yield. Dry weight of those samples was measured. Seedling vigor index was calculated according to the following formula (Jayraj and Karivaratharaju, 1992):

Seedling vigour index $=$ Mean germination $(\%)$

$\mathrm{X}$ Dry matter content per seedling

\subsubsection{Electrical conductivity test}

For electrical conductivity test, a sample of 50 seed was taken from each treatment in a conical flask containing $50 \mathrm{ml} \mathrm{de}$ - ionized water and was incubated at $20^{\circ} \mathrm{C}$ for 24 hours following Ali et al. (2004). After 20 hours, water of the beaker containing seeds was decanted in order to separate the seeds. The electrical conductivity of the decanted water containing seed leachate was measured with a conductivity meter (Model-CM$30 \mathrm{ET})$. Four repetition measures were made for each sample of seed.

\subsubsection{Observation of biotic factors}

For the observation of biotic factors that influence seed quality, $50 \mathrm{~g}$ of seeds was taken and the number and kind of insect or pathogens present were observed.

\subsubsection{Statistical analysis}

Analysis of variance was conducted using MSTAT-C software (Russel and Eisensmith, 1993) and significance of differences among means was compared employing least significant difference (LSD) test at a 0.05 probability level.

\section{Results and Discussion}

\subsection{0-seed weight and moisture content of soybean as influenced by storage container and storage period}

Effect of containers and storage periods on 1000seed weight and moisture content of soybean seeds are presented in Table 1. Storage container showed significant effect on 1000-seed weight and moisture content at different storage periods. At 0-day storage, 1000-seed weight of different containers' seeds was similar (74.85 g) but it increased with increasing storage time. The maximum 1000- seed weight was recorded in cloth bag, while the lowest was in tin container at 15, 30, 45 and 60 days after storage (DAS), respectively. In addition, the initial moisture content was similar $(8.30 \%)$ in different containers' seeds, but it increased with the increase in storage period. Seeds in cloth bag gave the highest moisture and tin container resulted in the lowest moisture at 15, 30, 45 and 60 DAS, respectively which was significantly different from those in polythene bag, except 15 DAS. 
Table 1. Effect of storage containers and storage periods on 1000- seed weight and moisture content of soybean

\begin{tabular}{lcccccccccc}
\hline & \multicolumn{4}{c}{1000 -seed weight $(\mathrm{g})$ at } & \multicolumn{5}{c}{ Moisture content $(\%)$ at } \\
\cline { 2 - 10 } Containers & $\begin{array}{l}\text { 0-day } \\
\text { storage }\end{array}$ & $\begin{array}{c}15 \\
\text { DAS }\end{array}$ & $\begin{array}{c}30 \\
\text { DAS }\end{array}$ & $\begin{array}{c}45 \\
\text { DAS }\end{array}$ & $\begin{array}{c}60 \\
\text { DAS }\end{array}$ & $\begin{array}{c}\text { 0-day } \\
\text { storage }\end{array}$ & $\begin{array}{c}15 \\
\text { DAS }\end{array}$ & $\begin{array}{c}30 \\
\text { DAS }\end{array}$ & $\begin{array}{c}45 \\
\text { DAS }\end{array}$ & $\begin{array}{c}60 \\
\text { DAS }\end{array}$ \\
\hline $\begin{array}{l}\text { Tin } \\
\text { container }\end{array}$ & 74.85 & $75.45 \mathrm{~b}$ & $77.51 \mathrm{c}$ & $79.97 \mathrm{~b}$ & $82.11 \mathrm{~b}$ & 8.3 & $8.38 \mathrm{~b}$ & $8.55 \mathrm{c}$ & $9.78 \mathrm{c}$ & $10.88 \mathrm{c}$ \\
$\begin{array}{l}\text { Polythene } \\
\text { bag }\end{array}$ & 74.85 & $77.35 \mathrm{a}$ & $80.42 \mathrm{~b}$ & $81.78 \mathrm{ab}$ & $85.74 \mathrm{a}$ & 8.3 & $8.60 \mathrm{~b}$ & $9.15 \mathrm{~b}$ & $11.61 \mathrm{~b}$ & $13.15 \mathrm{~b}$ \\
Cloth bag & 74.85 & $79.14 \mathrm{a}$ & $82.25 \mathrm{a}$ & $84.66 \mathrm{a}$ & $87.20 \mathrm{a}$ & 8.3 & $8.90 \mathrm{a}$ & $10.85 \mathrm{a}$ & $12.90 \mathrm{a}$ & $15.01 \mathrm{a}$ \\
\hline LSD 0.05 & & 1.83 & 3.93 & 3.38 & 2.80 & & 0.25 & 0.26 & 0.40 & 0.24 \\
$\mathrm{CV}(\%)$ & 4.57 & 3.07 & 2.57 & 2.06 & & 1.84 & 1.68 & 2.19 & 1.16 \\
\hline
\end{tabular}

Means followed by different letters within same column are significantly different by the LSD test at 0.05 level; DAS $=$ Days after storage

Table 2. Effect of storage containers and storage periods on germination percentage and germination index of soybean seed

\begin{tabular}{|c|c|c|c|c|c|c|c|c|c|c|}
\hline \multirow[b]{2}{*}{ Containers } & \multicolumn{5}{|c|}{ Germination (\%) at } & \multicolumn{5}{|c|}{ Germination index (GI) at } \\
\hline & $\begin{array}{c}\text { 0-day } \\
\text { storage }\end{array}$ & $\begin{array}{c}15 \\
\text { DAS }\end{array}$ & $\begin{array}{c}30 \\
\text { DAS }\end{array}$ & $\begin{array}{c}45 \\
\text { DAS }\end{array}$ & $\begin{array}{c}60 \\
\text { DAS }\end{array}$ & $\begin{array}{c}0 \text {-day } \\
\text { storage }\end{array}$ & $\begin{array}{c}15 \\
\text { DAS }\end{array}$ & $\begin{array}{c}30 \\
\text { DAS }\end{array}$ & $\begin{array}{c}45 \\
\text { DAS }\end{array}$ & $\begin{array}{c}60 \\
\text { DAS }\end{array}$ \\
\hline $\begin{array}{l}\text { Tin } \\
\text { container }\end{array}$ & 83.00 & $82.25 \mathrm{a}$ & $81.75 a$ & $81.00 \mathrm{a}$ & $79.75 a$ & 17.03 & $16.98 \mathrm{a}$ & $16.10 \mathrm{a}$ & $15.34 \mathrm{a}$ & $13.89 \mathrm{a}$ \\
\hline $\begin{array}{l}\text { Polythene } \\
\text { bag }\end{array}$ & 83.00 & $80.0 \mathrm{ab}$ & $78.25 b$ & $76.50 \mathrm{~b}$ & $72.50 \mathrm{~b}$ & 17.03 & $15.53 b$ & $14.22 \mathrm{~b}$ & $12.93 b$ & $11.88 b$ \\
\hline Cloth bag & 83.00 & $78.75 b$ & $76.50 \mathrm{c}$ & $71.25 \mathrm{c}$ & $66.50 \mathrm{c}$ & 17.03 & $14.74 b$ & $13.06 \mathrm{c}$ & $12.02 b$ & $10.97 \mathrm{c}$ \\
\hline $\mathrm{LSD}_{0.05}$ & & 2.69 & 1.89 & 6.30 & 4.36 & & 0.83 & 0.73 & 1.59 & 0.36 \\
\hline $\mathrm{CV}(\%)$ & & 2.10 & 1.49 & 5.17 & 3.73 & & 3.30 & 3.17 & 7.40 & 1.83 \\
\hline
\end{tabular}

Means followed by different letters within same column are significantly different by the LSD test at 0.05 level; DAS $=$ Days after storage

1000-seed weight and moisture content were increased gradually up to 60 DAS and were higher in cloth bag. As seed is highly hygroscopic living material; it absorbs moisture from air. The rate of absorbance was higher in cloth bag because of cloth bag is not air tight container, whereas tin container and polythene bag are moisture proof. The hydrophilic nature of high protein content of soybean helps in more absorption of water, increases the hydrolytic enzyme activity, enhances respiration and increases in free fatty acid content and finally, deteriorates the seed quality (Monira et al., 2012; Khalequzzaman et al., 2012). 
3.2. Germination percentage (GP) and germination index (GI) of soybean seed as influenced by storage container and storage period

Germination is the most important function of a seed as an indicator of its viability and worth as seed. There was a significant difference in the percentage of germination due to different storage containers for all storage periods in the study (Table 2). Seeds packed in tin container retained seed viability for longer time than in cloth bags. Initial germination was $83.00 \%$ for all containers at 0 -day storage. Both germination percentage (GP) and germination index (GI) decreased with the increase of storage period. The highest GP and GI were recorded for seeds in tin container, whereas the lowest values were recorded in cloth bag at 15,30, 45 and 60 DAS, respectively, which were statistically identical to polythene bag at 15 DAS.

Germination of soybean seeds was reported to be affected by storage containers during storage period (Shelar, 2008; Singh and Dadlani, 2003). Harrington (1973) found that a package which is moisture proof or moisture resistant would be more valuable in prolonging germination ability and vigor. Germination percentage and germination index of soybean seeds were decreased gradually in cloth bag. The reduction was more accentuated as the moisture content of the grains increased. By increasing moisture content from 8.3 to $15.01 \%$ in cloth bag (Table 1 ), the rate of germination percentage decreased from 83 to $66.50 \%$; and germination index decreased from 17.03 to $10.97 \%$ at 60 DAS (Table 2). During the storage period $70-82 \% \mathrm{RH}$ was prevailing. That's why initial moisture content of the seeds of non-air tight cloth bag was low and it increased over time by absorbing moisture from the surrounding atmosphere. The warm temperature and concomitant high relative humidity in the store reduced seed viability due to increased respiratory activity, decreased stored food materials and increased degree of invasion by seed-borne or storage fungi (Dejene, 2004).

\subsection{Abnormal seedling and dead seed of soybean as affected by storage container and storage period}

Abnormal seedling and number of dead seed increased with the increase of storage period (Table 3). The initial abnormal seedling was $6.00 \%$ for all containers at 0-day storage. The highest abnormal seedling percentage was recorded in cloth bag and the lowest values were recorded in tin container, which were identical to those in polythene bag at 15 and 45 DAS, respectively. The initial dead seed in tin container, polythene bag and cloth bag was $4.25 \%$, but it increased with increasing storage time.

Table 3. The existence of abnormal seedlings and dead seeds of soybean as affected by storage containers and storage periods

\begin{tabular}{|c|c|c|c|c|c|c|c|c|c|c|}
\hline \multirow[b]{2}{*}{ Containers } & \multicolumn{5}{|c|}{ Abnormal seedling (\%) at } & \multicolumn{5}{|c|}{ Dead seed (\%) at } \\
\hline & $\begin{array}{l}0 \text {-day } \\
\text { storage }\end{array}$ & $\begin{array}{c}15 \\
\text { DAS }\end{array}$ & $\begin{array}{c}30 \\
\text { DAS }\end{array}$ & $\begin{array}{c}45 \\
\text { DAS }\end{array}$ & $\begin{array}{c}60 \\
\text { DAS }\end{array}$ & $\begin{array}{c}0 \text {-day } \\
\text { storage }\end{array}$ & $\begin{array}{c}15 \\
\text { DAS }\end{array}$ & $\begin{array}{c}30 \\
\text { DAS }\end{array}$ & $\begin{array}{c}45 \\
\text { DAS }\end{array}$ & $\begin{array}{c}60 \\
\text { DAS }\end{array}$ \\
\hline $\begin{array}{l}\text { Tin } \\
\text { container }\end{array}$ & 6.00 & $6.75 b$ & $7.25 \mathrm{~b}$ & $7.50 \mathrm{~b}$ & $8.00 \mathrm{c}$ & 4.25 & $4.50 \mathrm{c}$ & $5.25 \mathrm{~b}$ & $5.75 \mathrm{c}$ & $7.50 \mathrm{~b}$ \\
\hline $\begin{array}{l}\text { Polythene } \\
\text { bag }\end{array}$ & 6.00 & $7.00 \mathrm{~b}$ & $8.25 \mathrm{ab}$ & $9.50 \mathrm{~b}$ & $10.50 \mathrm{~b}$ & 4.25 & $5.50 \mathrm{~b}$ & $6.75 \mathrm{ab}$ & $7.75 b$ & $9.75 b$ \\
\hline $\begin{array}{l}\text { Cloth } \\
\text { bag }\end{array}$ & 6.00 & $8.50 \mathrm{a}$ & $9.75 \mathrm{a}$ & $12.5 \mathrm{a}$ & $15.50 \mathrm{a}$ & 4.25 & $6.50 \mathrm{a}$ & $8.50 \mathrm{a}$ & $11.50 \mathrm{a}$ & $14.50 \mathrm{a}$ \\
\hline $\mathrm{LSD}_{0.05}$ & & 1.83 & 1.71 & 2.07 & 2.50 & & 0.92 & 3.71 & 3.13 & 2.96 \\
\hline CV (\%) & & 15.41 & 12.68 & 13.13 & 13.80 & & 10.50 & 33.97 & 23.49 & 17.47 \\
\hline
\end{tabular}

Means followed by different letters within same column are significantly different by the LSD test at 0.05 level; DAS $=$ Days after storage 
The highest dead seed percentage was recorded in cloth bag, whereas the lowest values were recorded in tin container at 15, 30, 45 and 60 DAS, respectively, which was statistically identical to those in polythene bag at 60 DAS.

The maximum abnormal seedlings and dead seeds were recorded in cloth bag and the minimum in tin container. Increasing rate of abnormal seedling and dead seed was observed higher in cloth bag, due to high moisture and fungal activities in soybean (Monira et al., 2012). Seed quality deterioration during storage was due to the damage to membrane, enzyme, proteins and nucleic acid. With the accumulation of time, such degenerative changes result in complete disorganization of membranes and cell organelles and ultimately causing death of the seed (Roberts, 1972).

\subsection{Seedling growth of soybean as affected by storage container and storage period}

Seed quality of soybean was evaluated by seedling characters, i.e. length and weight of seedling. Seedling growth is considered to be important tool that can be used for assessing the magnitude of deterioration. Seedling characters like shoot length, root length varied over storage containers and storage period. Storage container showed significant effect on root length and shoot length which decreased with the increase in storage period (Table 4). Initial root length was $16.48 \mathrm{~cm}$ and shoot length was $33.76 \mathrm{~cm}$ for all containers at 0 -day storage. Seeds in tin container gave the highest root and shoot length and cloth bag resulted in the lowest root and shoot length at 15, 30, 45 and 60 DAS, respectively. Moisture content had the influential effect on seed storage and high moisture content in cloth bags obviously deteriorated seedling growth (Copeland, 1976).

\subsection{Seedling dry matter of soybean as affected by storage container and storage period}

Seedling dry weight of soybean seed was obtained for seed of three containers (tin container, polythene bag, and cloth bag) which indicate that dry weight of cloth bags' seedling was lower than the other container's seed (Table 5). Seedling dry weight per plant was decreased with the increase of storage period. Initial soybean seedling dry weight was $33.13 \mathrm{mg}$ plant $^{-}$ ${ }^{1}$ for all containers at 0 -day storage. The highest seedling dry weight per plant was obtained from tin container for all storage periods. On the contrary, the lowest dry weight per plant was recorded from cloth bag for all storage periods, which was statistically identical to that in polythene bag at 30 DAS.

The deterioration of seed due to high moisture absorption in cloth bags, which is a progressive process accompanied by accumulation of metabolites, and which progressively depresses germination and growth of seedling with increased age, ultimately reduces the dry matter and vigour of soybean seeds during storage.

\subsection{Vigour index of soybean as affected by storage container and storage period}

Effects of containers and storage periods on seed and seedling vigour index of soybean are presented in Table 6 . Both seed and seedling vigour index were decreased with the increase of storage period. Initial seed vigour index was 4169.92 for all containers at 0-day storage. Storage containers had significant effect on seed vigour index. Seed vigour index was decreased with the increase of storage period. The highest seed vigour index was obtained from tin container, and the lowest vigour index was obtained from cloth bag for all storage periods. Initial seedling vigour index was 2749.79 for all containers. The highest seedling vigour index was obtained from tin container, and the lowest seedling vigour index was obtained from cloth bag at 45 and 60 DAS. The highest seed and seedling vigour index was obtained from tin container, which was followed by polythene bag and the lowest were obtained from cloth bag for all storage periods, which might be due to low vigour of seeds for long storage periods, high moisture and fungi infestation (Singh and Dadlani, 2003). 
Table 4. Effect of storage containers and storage periods on root length and shoot length of soybean seedlings

\begin{tabular}{lcccccccccc}
\hline & \multicolumn{4}{c}{ Root length (cm/plant) at } & \multicolumn{5}{c}{ Shoot length (cm/plant) at } \\
\cline { 2 - 10 } Containers & $\begin{array}{l}\text { 0-day } \\
\text { storage }\end{array}$ & $\begin{array}{c}15 \\
\text { DAS }\end{array}$ & $\begin{array}{c}30 \\
\text { DAS }\end{array}$ & $\begin{array}{c}45 \\
\text { DAS }\end{array}$ & $\begin{array}{c}60 \\
\text { DAS }\end{array}$ & $\begin{array}{c}\text { 0-day } \\
\text { storage }\end{array}$ & $\begin{array}{c}15 \\
\text { DAS }\end{array}$ & $\begin{array}{c}30 \\
\text { DAS }\end{array}$ & $\begin{array}{c}\text { DAS } \\
\text { DAS }\end{array}$ \\
\hline $\begin{array}{l}\text { Tin } \\
\text { container }\end{array}$ & 16.48 & $14.15 \mathrm{a}$ & $13.98 \mathrm{a}$ & $13.28 \mathrm{a}$ & $12.07 \mathrm{a}$ & 33.76 & $33.01 \mathrm{a}$ & $32.49 \mathrm{a}$ & $31.78 \mathrm{a}$ & $29.90 \mathrm{a}$ \\
$\begin{array}{l}\text { Polythene } \\
\text { bag }\end{array}$ & 16.48 & $13.27 \mathrm{~b}$ & $12.01 \mathrm{~b}$ & $10.75 \mathrm{~b}$ & $8.64 \mathrm{~b}$ & 33.76 & $31.34 \mathrm{~b}$ & $29.28 \mathrm{~b}$ & $27.80 \mathrm{~b}$ & $24.53 \mathrm{~b}$ \\
$\begin{array}{l}\text { Cloth } \\
\text { bag }\end{array}$ & 16.48 & $12.20 \mathrm{c}$ & $10.42 \mathrm{c}$ & $8.13 \mathrm{c}$ & $6.02 \mathrm{c}$ & 33.76 & $29.55 \mathrm{c}$ & $27.06 \mathrm{c}$ & $23.65 \mathrm{c}$ & $20.93 \mathrm{c}$ \\
\hline $\begin{array}{l}\text { LSD } \\
\text { C.05 }\end{array}$ & & 0.87 & 0.75 & 0.42 & 1.10 & & 1.03 & 1.93 & 2.44 & 2.52 \\
$\mathrm{CV}(\%)$ & & 4.14 & 3.84 & 2.47 & 7.73 & & 2.06 & 4.07 & 5.51 & 6.27 \\
\hline
\end{tabular}

Means followed by the different letter within same column are significantly different by the LSD test at 0.05 level; DAS $=$ Days after storage

Table 5. Effect of storage containers and storage periods on dry weight $(\mathrm{mg})$ per plant of soybean seedlings

\begin{tabular}{|c|c|c|c|c|c|}
\hline \multirow{2}{*}{ Containers } & \multicolumn{5}{|c|}{ Dry weight (mg/plant) at } \\
\hline & 0-day storage & 15 DAS & 30 DAS & 45 DAS & 60 DAS \\
\hline Tin container & & $32.01 \mathrm{a}$ & $29.18 \mathrm{a}$ & $28.00 \mathrm{a}$ & $26.15 a$ \\
\hline Polythene bag & $33.13^{\mathrm{NS}}$ & $26.48 \mathrm{ab}$ & $23.31 b$ & $20.75 b$ & $16.60 \mathrm{~b}$ \\
\hline Cloth bag & & $23.60 \mathrm{~b}$ & $19.05 b$ & $15.30 \mathrm{c}$ & $11.05 \mathrm{c}$ \\
\hline $\mathrm{LSD}_{0.05}$ & & 6.74 & 5.30 & 5.76 & 1.82 \\
\hline $\mathrm{CV}(\%)$ & & 15.40 & 13.90 & 16.87 & 6.35 \\
\hline
\end{tabular}

Means followed by the different letter within same column are significantly different by the LSD test at 0.05 level; DAS $=$ Days after storage

\subsection{Electrical conductivity (EC) of soybean seed as affected by storage container and storage period}

Electrical conductivity (EC) test of seed leachate provides a quick decision about seed vigour. Storage containers had significant effect on EC of soybean seed (Table 7). Initial EC of seed leachate was $89.27 \mu \mathrm{S} \mathrm{cm}^{-1}$ for all containers at 0 -day storage. The highest EC of seed leachate was recorded from the seeds stored in cloth bag for all storage periods. Conversely, the lowest EC was recorded from tin container for all storage periods, which was statistically identical to polythene bag at 15 DAS.
EC of seeds showed a highly negative correlation with germination percentage (Fig. 1). The negative relationship between EC and seed germination indicated that more cells leachate escaped from low quality seed and lowered the germination capacity of soybean seed, which is in agreement with the findings of Halim et al. (2012) in onion seeds. High EC of seed is assumed due to membrane deterioration during the imbibitions period of lower quality seeds. In tin container, the quality of seed was good and that is why they leak less leachate compared to that of low quality seeds stored in cloth bag. The vigour of cloth bag's seed was decreased over time of storage due to greater moisture absorption (Baki and Anderson, 1970). 
Table 6. Effect of storage containers and storage periods on seed and seedling vigour index of soybean

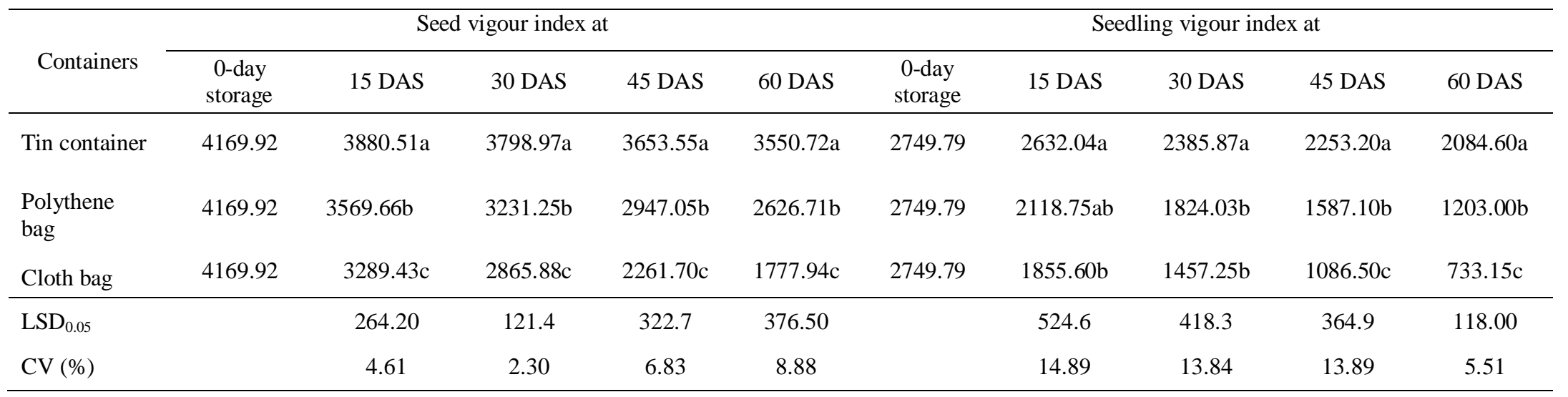

Means followed by the different letter within same column are significantly different by the LSD test at 0.05 level; DAS = Days after storage

Table 7. Effect of storage containers and storage periods on the electrical conductivity (EC) of soybean seed

\begin{tabular}{|c|c|c|c|c|c|}
\hline \multirow{2}{*}{ Containers } & \multicolumn{5}{|c|}{ Electrical conductivity $\left(\mu \mathrm{S} \mathrm{cm}^{-1}\right)$ at } \\
\hline & 0-day storage & $15 \mathrm{DAS}$ & 30 DAS & 45 DAS & 60 DAS \\
\hline Tin container & & $126.75 b$ & $195.25 \mathrm{c}$ & $214.88 \mathrm{c}$ & $291.50 \mathrm{c}$ \\
\hline Polythene bag & $89.27^{\mathrm{NS}}$ & $172.25 b$ & $258.75 b$ & $308.75 b$ & $427.75 b$ \\
\hline Cloth bag & & $220.00 \mathrm{a}$ & $319.50 \mathrm{a}$ & $441.25 \mathrm{a}$ & $715.76 a$ \\
\hline $\operatorname{LSD}_{0.05}$ & & 47.72 & 55.97 & 56.93 & 106.00 \\
\hline $\mathrm{CV}(\%)$ & & 17.25 & 13.57 & 11.07 & 13.86 \\
\hline
\end{tabular}

Means followed by the different letter within same column are significantly different by the LSD test at 0.05 level; DAS = Days after storage 


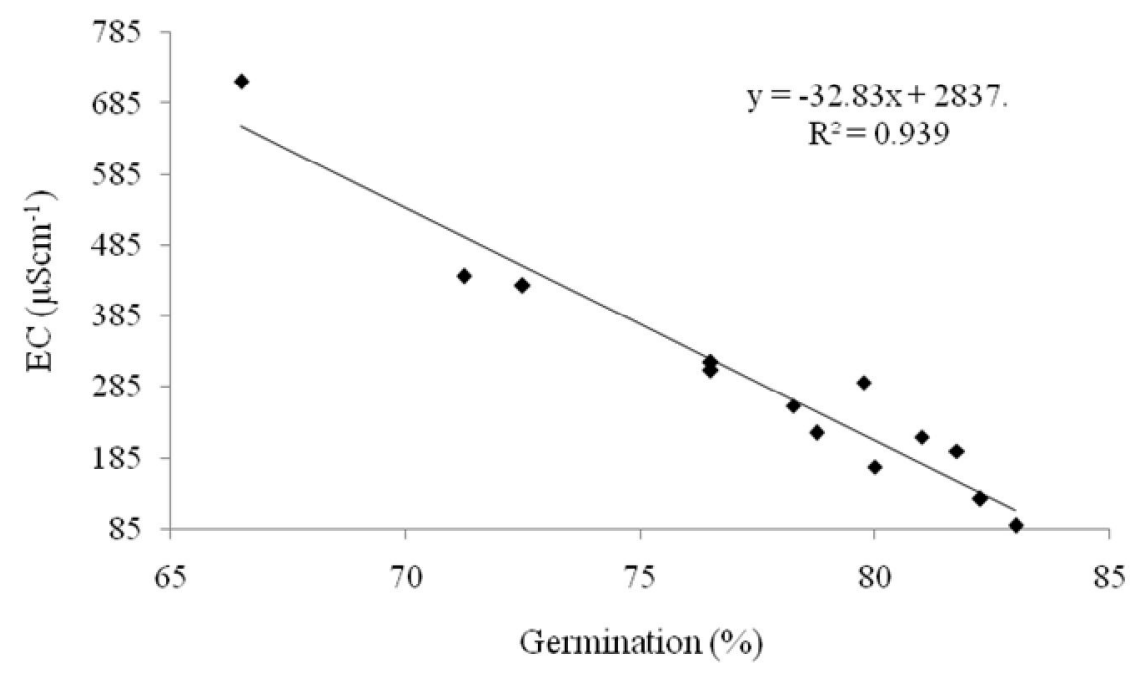

Fig. 1. Relationship between germination (\%) and electrical conductivity (EC) of soybean seeds

\subsection{Effect of Biotic Factors}

Biotic factors like insect and fungi were investigated during the storage period in different storage containers. No insect was found in any storage container for the whole storage periods. In general, prevalence of fungi was found higher in the seeds of cloth bag and the lowest was found in seeds of tin containers. Number of dead seeds (Table 3) indicates the presence of fungi but these were not identified by any pathological test.

\subsection{Seed colour of soybean as affected by storage container and storage period at 60 DAS}

Initial seed colour of soybean was yellowish. After 60 days of storage, seed colour of tin container was similar as initial colour, but seeds of cloth bag changed into fade or brown colour. Fade or brown colour might be due to increased moisture and fungi infestation (Khalequzzaman, 2012) in cloth bags.

\section{Conclusions}

The soybean grains generally deteriorated with storage and deterioration was particularly strong for grains stored in cloth bag. High temperature, high relative humidity, and moisture in the storage environment are the principal factors involved in deterioration of soybean seed quality during storage. Loss of germination capacity was the final manifestation of seed deterioration. When seed moisture content was increasing the rate of germination percentage was decreased. The deterioration rate was also the highest in seeds of cloth bag. The electrical conductivity, abnormal seedling and dead seed were increased with increasing storage time, but the increasing rate was higher in seeds of cloth bag. The shoot and root length of seedling and seedling vigour was the lowest in cloth bag at the end of storage period. Dry weight per plant of soybean decreased in all cases but the rate of deterioration was also the highest in cloth bag. 
It may be concluded that the conventional practices of soybean seed storage in cloth bags are not suitable because there is a possibility of moisture gain and pests attack, which play important role in deterioration of soybean seed quality and viability during storage. Air tight tin container will be the best means for soybean seed storage for long time.

\section{References}

Ali, S. M. M., Haque, M. M., Siddique, A. B., Mollah, A. F. and Islam, M. N. 2004. Effect of sowing date on the viability and vigour of tossa jute (Corchorus olitorius L.) seed in late sown condition. SAARC Journal of Agriculture, 2: 23-38.

Amin, A. K. M., Jahan, S. R. A., Karim, M. F. and Hasanuzzaman, M. 2009. Growth dynamics of soybean (Glycine max L.) as affected by varieties and timing of irrigation. American-Eurasian Journal of Agronomy, 2(2): 95-103.

Anonymous, 1999. International Rules for Seed Testing. International Seed Testing Association (ISTA), Seed Science and Technoogy, 4: 3-177.

Anonymous, 2011. Krishi Diary 2011. Agricultural Information Service, Khamarbari, Farmgate, Dhaka 1215, 573 p.

Assefa, M. K. 2008. Effect of seed priming on storability, seed yield and quality of soybean [Glycine $\max$ (L.) Merrill]. MS thesis, University of Agricultural Sciences, Dharwad 580005.

Association of Official Seed Analysis (AOSA). 1983. Seed Vigor Testing Handbook. Contribution No. 32. Association of Official Seed Analysts. Lincoln, NE, USA, $89 \mathrm{p}$.

Baki, A. A. and Anderson, J. D. 1970. Vigour determination in soybean seed by multiple criteria. Crop Science, 13: 630-633.
BARI (Bangladesh Agricultural Research Institute). 1993. Intensive vegetable growing and its utilization. Bangladesh Agricultural Research Institute, Joydebpur, Gazipur, 245 p.

BBS (Bangladesh Bureau of Statistics). 2009. Statistical Yearbook of Bangladesh 2009 \& Crop Summary. Statistics Division, Ministry of Planning, Govt. of the People's Republic of Bangladesh, Dhaka.

Copeland, L. O. 1976. Principles of Seed Science and Technology. Burgess Pub. Com; Minncapolis, Minnesota, 164-165 pp.

Dejene, M. 2004. Grain storage methods and their effects on sorghum grain quality in Hararge, Ethopia. PhD thesis, Swedish University of Agriculture Sciences, 1-29 pp.

Halim, M. A., Hossain, M. M., Haque, M. M. and Solaiman, A. R. M. 2012. Seed quality of onion as influenced by maturity stage. Seed Technology Journal, 3: 9-12.

Harrington, J. F. 1973. Packaging seed for storage and shipment. Seed Science and Technology, 1: 701-709.

Heydecker, W. 1979. The vigor of seeds- a review. Proceedings of the International Seed Testing association, 34: 201- 209.

ISTA (International Seed Testing Association). 1999. International Rules for Seed Testing. International Seed Testing Association. Seed Science and Technology, 4: 3-177.

Jayraj, T. and Karivaratharaju, T. V. 1992. Influence of harvesting stage on seed vigour of groundnut cultivars. Seed Research, 20(1): 41-43.

Khalequzzaman, K. M., Rashid, M. M., Hasan, M. A. and Reza, M. M. A. 2012. Effect of storage containers and storage periods on the seed quality of French bean (Phaseolus vulgaris L.). Bangladesh 
Journal of Agricultural Research, 37(2): 195-205.

Krishnasamy, V. and Seshu, D. V. 1990. Germination after accelerated ageing and associated characters in rice varieties. Seed Science and Technology, 18: 147157.

Monira, U. S., Amin, M. H. A., Aktar, M. M. and Mamun, M. A. A. 2012. Effect of containers on seed quality of storage soybean seed. Bangladesh Research Publications Journal, 7: 421-427.

Rahman, M. L. and Chowdhury, M. A. Z. 2010. Agricultural Research Priority: Vision2030 and beyond (Sub-sector: Pulses and Oil Crops). Bangladesh Agricultural Research Council, Farmgate, Dhaka, 15$18 \mathrm{pp}$.

Rahman, M. M., Rahman, M. M. and Hossain, M. M. 2013. Effect of sowing date on germination and vigour of soybean (Glycine max (L.) Merr) seeds. The Agriculturists, 11(1): 67-75.
Rahman, M. M., Hossain, M. M., Anwar, M. P. and Juraimi, A. S. 2011. Plant density influence on yield and nutritional quality of soybean seed. Asian Journal of Plant Sciences, 10(2): 125-132.

Roberts, E. H. 1972. Storage environment and control of viability. In: Viability of seeds, (ed.). E. H. Roberts, Chapman and Hall Limited, London, 14-18 pp.

Russel, D. F. and Eisensmith, S. P. 1993. MSTAT-C. Crop and Soil Science Department, Michigan State University, USA.

Shelar, V. R., Shaikh, R. S. and Nikam, A. S. 2008. Soybean seed quality during storage: A Review. Agricultural Reviews, 29(2): 125 - 131.

Singh, K. K. and Dadlani, M. 2003. Effect of packaging on vigour and viability of soybean [(Glycine max (L.) Merrill] seed during ambient storage. Seed Research, 31(1): 27-32. 